\title{
Tumors of the Pancreatic Body and Tail
}

\author{
Savio George Barreto ${ }^{a}$, Parul J. Shukla ${ }^{\mathrm{b}}$, Shailesh V. Shrikhande ${ }^{\mathrm{b}, \mathrm{c}}$
}

\begin{abstract}
Tumors of the pancreatic body and tail are uncommon. They have a propensity to present late and often attain a large size with local invasion before they produce any clinical symptoms. The current review aims at comprehensively analysing these tumors with respect to their pathology, presentation, the investigation of these tumors, and finally the latest trends in their surgical and medical management.
\end{abstract}

Keywords: Pancreatic tumor; Neuroendocrine; Cystic; Venous; Arterial

\section{Introduction}

Tumors of the body and tail of the pancreas constitute onethird of the pancreatic neoplasms. They have always been associated with a poor prognosis due to the late presentation, and hence, advanced stage of the disease at diagnosis. However, this trend is gradually on the decline with the awareness of the existence of these lesions, better radiologic imaging modalities for diagnosis, and the more aggressive treatment strategies adopted in these patients. This review, which will visit the entire spectrum of tumors that can present in the pancreatic body and tail, will also attempt to provide current strategies for the diagnosis and treatment of these uncommon yet, often, surgically challenging tumors.

\footnotetext{
Manuscript accepted for publication September 8, 2009

${ }^{\text {a } D e p a r t m e n t ~ o f ~ G e n e r a l ~ a n d ~ D i g e s t i v e ~ S u r g e r y, ~ F l i n d e r s ~ M e d i c a l ~}$ Centre, Adelaide - South Australia

${ }^{b}$ Department of Gastrointestinal Surgical Oncology, Tata Memorial

Hospital, Mumbai, India

${ }^{\mathrm{c}}$ Corresponding author: Gastrointestinal Surgical Oncology, Tata

Memorial Hospital, Parel, Mumbai 400 012, India.

Email: shailushrikhande@hotmail.com
}

doi:10.4021/wjon2010.04.200w

\section{Pathology}

Tumors in the body and tail include the entire spectrum of exocrine and endocrine neoplasms of the pancreas. Table 1 shows a classification of these lesions. The pathological features of the most common neoplasms are discussed below:

\section{Ductal adenocarcinoma}

Approximately $15 \%$ of these tumors are found in the body and tail. They grossly appear as white-yellow, poorly defined, firm masses often obstructing the main pancreatic duct. Microscopic appearance is that of infiltrative glands of various shapes and sizes surrounded by an intense desmoplastic response, extending beyond the grossly defined mass [1]. The nuclei of the cells show marked pleiomorphism, hyperchromasia, loss of polarity, and prominent nucleolei. The epithelial cells often contain mucin and may form papillae and cribriform structures. These tumors frequently invade the vascular, lymphatic, and perineural spaces.

\section{Cystic neoplasms}

The four main classes of cystic pancreatic tumors include the serous cystic, mucinous cystic, intraductal papillary mucinous, and the unusual neoplasms.

Serous cystadenomas (SCAs) vary in size from $6 \mathrm{~cm}$ to $10 \mathrm{~cm}$ although cysts of even $25 \mathrm{~cm}$ have been reported. They are well demarcated and are lined by simple, glycogen-rich cuboidal epithelium and characterized by dense, lace-like, honeycombed matrix of fibrous septae. They have been referred to as microcystic since they are made up of clusters of cysts that are filled with clear watery, non-mucinous and occasionally bloody fluid.

Mucinous neoplasms are made up of cysts that are larger in size than the serous neoplasias and are usually up to 25 $\mathrm{cm}$. The cyst contains mucinous, viscid fluid. The main features that help in distinguishing it from other cystic neoplasias include the presence of a dense mesenchymal ovarianlike stroma, and the lack of communcation with the main pancreatic ductal system [2, 3]. The Mayo Clinic has divided 
Table 2. Summary of the genetic alterations in pancreatic tumors according to histopathological type

\begin{tabular}{lll}
\hline Adenocarcinoma & Pancreatic endocrine tumors & $\begin{array}{l}\text { Intraductal papillary mucinous } \\
\text { tumors }\end{array}$ \\
\hline Sporadic & & \\
K - ras & Men-1 & K-ras \\
P53 & P16 & P53 \\
P16 & P27 & P16 \\
DPC4 & Cyclin D & \\
Hereditary & DPC4 & \\
PRSS1 & & \\
FAMM (p16) & Men-1 & \\
STK11/LKB1 & Von Hippel Lindau (VHL) \\
BRCA 2 & Von Recklinghausen's & \\
HNPCC & disease (NF-1) & \\
Li Fraumeni Syndrome (p53) & Tuberous Sclerosis & \\
\hline
\end{tabular}

tion.

Solid and cystic papillary and epithelial neoplasias (SPEN) have a variegated appearance with solid, cystic, and papillary areas with foci of necrosis and haemorrhages. The degenerative areas have been attributed to vascular ischaemia [10]. The most useful markers are alpha-1-1antitrypsin, alpha-1-antichymotrypsin, neuron specific enolase (NSE), and Vimentin [11].

\section{Endocrine tumors [12]}

1) Insulinoma. Grossly, $40 \%$ of these tumors are $<1 \mathrm{~cm}$, and $66 \%$ are $<1.5 \mathrm{~cm}$ [13]. They present as encapsulated, firm, brown, nodules that are histologically composed of cords and nests of well-differentiated $\beta$ cells that do not differ from the normal islet cells. 2) Gastrinoma. The tumor size in the pancreas is usually above $2 \mathrm{~cm}$ and in the duodenum below $1 \mathrm{~cm}$, often very tiny and often multicentric. More than $85 \%$ are identifiable in an anatomical triangle bordered by cystic duct, the junctions of the second and third portions of the duodenum, and the junction of the neck and body of the pancreas that has been referred to as the 'Gastrinoma Triangle' [14]. 3) Glucagonoma. The histology of the tumor is similar to the entire group of neuroendocrine tumors with the basic difference being the production and release of large quantities of glucagons. 4) VIPoma, PPoma, etc, share the same histology except for the basic difference of the hormone produced.

The aggressiveness of the tumor is defined not by the histology but rather by the behavior.

\section{Genetics}

A summary of the genetic changes encountered in ductal adenocarcinomas, endocrine tumors, and intraductal papillary mucinous neoplasms are listed in Table 2 [15].

\section{Clinical presentation}

Tumors of the body and tail, in general, tend to present late until they produce a clinically discernible swelling. By this time the tumor is usually infiltrating adjacent organs or vascular structures and possibly metastasized via lymphatics to locoregional lymph nodes, or by haematogenous dissemination to distant organs $[16,17]$. The difference in the time to detection as compared to the tumors in the head is due to the lack of obstructive symptoms of the biliary and gastric systems. The functioning neuroendocrine tumors, with their characteristic symptom complexes, can be detected provided the clinician is quick to recognize these features.

The most common symptoms encountered are pain (epigastric, and radiating to the back, in case of celiac plexus involvement), weight loss, and new onset diabetes mellitus (especially in patients $>60 \mathrm{yrs}$ ). The commonly encountered nonspecific symptoms include anorexia, loss of appetite, weakness and lethargy. 
Table 3. CT criteria for vascular invasion

\author{
Arterial embedment in tumor mass or venous obliteration \\ Tumor involvement exceeding one-half circumference of the vessel \\ Vessel wall irregularity \\ Vessel calibre stenosis \\ eardrop sign of the superior mesenteric vein
}

The presence of a palpable tumor inadvertently points to a diagnosis of cystadenoma (esp. mucinous carcinomas) [18] or islet cell tumor, as adenocarcinoma is rarely palpable prior to demise [19].

Cystic tumors of the pancreas, when symptomatic (approx. $25-60 \%$ ) [9, 20], produce pressure symptoms. These are more commonly seen in mucinous tumors with the incidence of symptoms correlating with the risk of malignancy. Abdominal pain weight loss and diarrhoea are common [21]. The less common symptoms are constipation, diarrhoea, abdominal distension, fatigue, early satiety, and in the rare event of functioning tumors, the patient may show signs of hypoglycemia [22]. Hemorrhagic complications secondary to gastric involvement, portal hypertension, haemobilia, or haemosuccus pancreaticus, can be seen in malignant mucinous neoplasms $[23,24]$. In rare cases of SPEN, patients have presented with acute abdominal pain due to rupture of the tumor [25]. IPMNs, when symptomatic, present with signs of chronic pancreatitis and pancreatic exocrine insufficiency, i.e. pain, steatorrhoea, weight loss, urgency, diabetes, etc. They can also present as acute or recurrent pancreatitis. The main distinguishing feature is the lack of aetiology for acute pancreatitis on obtaining a history in such a patient. Diabetes is found to be associated with mucinous tumors especially those that are malignant [26]. Rare associations with Peutz-Jeghers and Zollinger Ellison syndrome have been described $[27,28]$.

Endocrine tumors present with characteristic syndrome complexes. Insulinomas are characterised by the Whipples triad that includes symptoms of hypoglycemia accompanied by plasma glucose levels $<3.0 \mathrm{mmol} / \mathrm{L}$ relieved by glucose administration [29]. Gastrinomas lead to symptoms of peptic ulcer disease $(90 \%)$ often not responsive to acid suppressive therapy or associated with relapse despite therapeutic compliance [30]. Glucagonomas present with a rash described as dermatitis necrolysis migrans, anaemia, and weight loss. Diabetes mellitus is present in $75-95 \%$ patients with glucagonomas [31]. Patients with somatostatinomas show a constellation of nonspecific problems. In more than $50 \%$ of these patients, a characteristic set of findings is cholelithiasis, steatorrhoea, hyperchlorhydria, and weight loss [12]. The other endocrine tumors of the pancreas are less com- monly found in the body and tail.

\section{Diagnosis}

Computed tomography (CT) scan has always been the primary imaging modality of choice in patients with pancreatic neoplasms. The advent of multi detector row helical CT (MDR CT) has reestablished CT as an important preoperative investigation. Endoscopic ultrasonography (EUS) has been also found to be useful in patients with tumors of the body and tail where a transgastric window is used for imaging and fine needle aspiration cytology (FNAC) [32]. Earlier studies had shown contrast enhanced magnetic resonance imaging (MRI) to be as accurate as helical CT in the detection and staging of pancreatic cancer [33]. However, a recent study comparing EUS, MDR CT, MRI and angiography for assessing pancreatic cancer staging and resectability demonstrated that MDR CT has the highest accuracy in assessing extent of primary tumor $(73 \%)$, locoregional extension $(74 \%)$, vascular invasion $(83 \%)$, distant metastases $(88 \%)$, tumor TNM stage (46\%), and tumor resectability (83\%). EUS, however, remained the modality of choice for imaging small lesions undetectable by $\mathrm{CT}$ as it has the highest accuracy in assessing tumor size and lymph node involvement [34]. A recent meta-analysis comparing MDR CT, MRI and ultrasonography for diagnosis and determining resectability in pancreatic cancer also proposed MDR CT (sensitivity, 91\%; specificity, $85 \%)$ as the preferred method [35].

MRI, however, continues to be the modality of choice for the detection of liver metastases owing to its ability to characterize liver lesions more accurately than even contrast enhanced MDR CT [36].

Magnetic resonance cholangio-pancreatography (MRCP), despite being a very sensitive test for the detection of pancreato biliary obstruction, has low accuracy in detecting malignant features [37]. It is thus not to be routinely recommended in tumors of the body and tail.

The CT criteria for vascular invasion have been listed in Table 3 [38]. Today, with the availability of vascular reconstructions, only arterial encasement is regarded as a sign of unresectability.

The sensitivity and specificity of EUS-FNA in the diag- 
nosis are said to approach 92 and 100\%, respectively [39].

Laparoscopic staging has emerged as a very effective tool in detection of intraperitoneal metastasis in patients with tumors of the body and tail [40]. This is especially so in patients with suspected advanced lesions and absence of metastasis on conventional imaging. Two studies have proven the existence of unsuspected metastasis in patients with pancreatic body and tail tumors to be $36-53 \%[41,42]$.

Regarding the tumor markers, while CA-125 may be of use in mucinous cystic neoplasms of the pancreas, the role of CA 19-9 is mainly of use when it is elevated where it helps to differentiate a malignancy from an acute inflammation. It has a sensitivity and specificity of $69-93 \%$ and $78-98 \%$, respectively with regards to detection of pancreatic cancers [43].

In case of endocrine tumors, there are specific tests for the diagnosis of each of them the principal ones being listed in Table 4.

Cystic neoplasms of the pancreatic body and tail are diagnosed by conventional imaging modalities coupled with EUS-FNA. The analysis of the cyst fluid obtained from a EUS-guided aspiration provides valuable information if analysed for biochemistry, tumor markers and not only cells as these aspirates tend to be paucicellular. In general, glycogenrich cells are specific for serous cystadenoma, mucin-containing cells are seen in mucinous cystadenomas, and malignant cells are seen in mucinous cystadenocarcinomas [44]. Sperti et al. [45], have suggested that 18-FDG PET may be better than $\mathrm{CT}$ and tumor marker assays in the preoperative evaluation of patients with cystic pancreatic lesions since a positive result strongly suggests malignancy, and hence surgery, while a negative result implies a benign lesion that may be treated by limited resection or, in selected high- risk patients, with biopsy, follow-up, or both.

\section{TNM staging of nonendocrine pancreatic tumors [46]}

Primary tumor $(\mathrm{T})$

TX: Primary tumor cannot be assessed

T0: No evidence of primary tumor

Tis: In situ carcinoma

T1: Tumor limited to the pancreas $2 \mathrm{~cm}$ or less in greatest dimension

T2: Tumor limited to the pancreas more than $2 \mathrm{~cm}$ in greatest dimension

T3: Tumor extends directly into any of the following: duodenum, bile duct, or peripancreatic tissues

T4: Tumor extends directly into any of the following: stomach, spleen, colon, or adjacent large vessels

Regional lymph nodes (N)

NX: Regional lymph nodes cannot be assessed

N0: No regional lymph node metastasis

N1: Regional lymph node metastasis
Distant metastasis (M)

MX: Distant metastasis cannot be assessed

M0: No distant metastasis

M1: Distant metastasis

AJCC stage groupings

Stage 0 Tis, N0, M0

Stage I T1, N0, M0

$\mathrm{T} 2, \mathrm{~N} 0, \mathrm{M} 0$

Stage II T3, N0, M0

Stage III T1, N1, M0

$\mathrm{T} 2, \mathrm{~N} 1, \mathrm{M} 0$

T3, N1, M0

Stage IVA T4, Any N, M0

Stage IVB Any T, Any N, M1

Criteria for resectability [47]

Resectable lesions

1) No distant metastases

2) Clear fat plane around celiac and superior mes enteric arteries (SMA)

3) Patent superior mesenteric vein (SMV)/portal vein

Borderline resectable lesions

1) Adrenal, colon or mesocolon, or kidney invasion

2) Preoperative evidence of biopsy positive peripan creatic lymph node

\section{Unresectable lesions}

Distant metastasis (includes celiac and/or paraaortic lymph node metastasis); Lesions that have the above two groups of lymph nodes that are, however, in close proximity to the primary may also be regarded as borderline rather than unresectable. For body, 1) SMA/celiac/hepatic encasement; 2) SMV/portal occlusion; 3) Aortic invasion. For tail, 1) SMA/celiac encasement; $2 \mathrm{Rib} /$ vertebral invasion.

\section{Management}

Brennan et al. suggested that in patients with tumors of the body and tail of the pancreas, the approach should be aggressive and similar to the approach towards patients with tumors of the head, i.e., surgery should be contemplated as the best currently available therapeutic modality esp. for patients without known metastatic disease or major vascular invasion [48]. While it has been found at the time of surgery that approximately $35 \%$ of patients [17] have evidence of involvement of surrounding structures either by tumor infiltration or inflammatory adhesions, it is advisable that to obtain negative surgical margins, distal pancreatectomy with/without splenectomy and even en bloc resections can be resorted to. It is true that while the operative mortality following distal pancreatectomy is less than $2 \%$ [49-50], the 
Table 4. Diagnostic tests for pancreatic endocrine tumors [12]

\begin{tabular}{ll}
\hline Tumor & Test \\
\hline Insulinoma & $\begin{array}{l}\text { Supervised } 72 \mathrm{hr} \text { fast, demonstrating Whipple's triad and } \\
\text { insulin/glucose ratio of }>0.3 \\
\text { Selective arteriogram with intraarterial calcium injection } \\
\text { and hepatic venous sampling } \\
\text { Elevated c-peptide proinsulin levels }\end{array}$ \\
& $\begin{array}{l}\text { Elevated serum gastrin levels } \\
\text { Elevated basal acid secretory rate } \\
\text { Secretin stimulation test }\end{array}$ \\
Glucagonoma & Elevated glucagon levels \\
Somatostatinoma & Elevated fasting plasma somatostatin levels \\
\hline
\end{tabular}

morbidity is around $22-47 \%[51,52]$. This is based on the findings that the median survival after a palliative resection is much shorter than after a curative resection [53]. Shoup et al. [16], based on their extensive experience with extended resections, have concluded that patients undergoing extended resection for the adenocarcinoma of the pancreatic body and tail have long-term survival rates similar to those for patients undergoing standard resection. They also found that this group of patients had a markedly improved long-term survival compared to those who are not considered resectable because of locally advanced disease.

The prognostic factors implicated to have a poor effect on the survival following resections for tumors in the body and tail include age over 60 years, size of the tumor over $3.5 \mathrm{~cm}$, and an advanced stage [17]. The exact significance of an R0 resection has been debated with studies showing contradicting results $[16,48,54]$. The current opinion, though, is to be radical in obtaining an R0 margin whenever feasible.

\section{Closure of the pancreatic remnant, staple or suture?}

The choice of closure of the pancreatic remnant has been a matter of debate with different strategies being adopted including the traditional hand-sewn closure, stapled closure, a combination of the sewn and stapled closures, application of fibrin glue or serosal patch and even the injection of prolamine [55]. Takeuchi et al. [56] found that the use of staplers to close the pancreatic remnant after a distal pancreatectomy was associated with a $0 \%$ fistula rate and was also simple and quick. A recently published meta analysis [57] that included six studies concluded that the available information showed a non-significant combined odds ratio for pancreatic fistula of $0.66(95 \%$ confidence interval 0.35 to $1.26, \mathrm{P}=0.21)$ in favor of staple closure. However, a large retrospective study including 302 patients that followed this meta-analysis indicated a higher pancreatic fistula rate following the stapled closure [58]. It thus, appears that till date there is a lack of an evidence-based superiority of any one technique over the other [59].

\section{Role for splenectomy}

While the need for spleen preservation has been propounded in benign lesions, Shoup et al. [60] have confirmed the need for splenectomy in adenocarcinomas to avoid compromising oncologic radicality.

\section{Role of laparoscopy}

Staging laparoscopy has been shown to be a useful aid in the staging of ductal adenocarcinomas of the body and tail. In one study, $20 \%$ of patients with body and tail tumors $(n=10)$ were found to have liver or peritoneal metastases that was undetected on preoperative imaging [61]. In another study in which two parameters (presence of gross metastases and peritoneal fluid cytology) were assessed in 47 patients with radiologically indicated operable disease, $36 \%$ of patients $(\mathrm{P}$ $<0.02$ ) were found to have inoperable disease based on these parameters [41].

For benign tumors, small islet cell tumors that have been well localized preoperatively, and for premalignant cystic lesions, laparoscopic enucleation and spleen-preserving distal pancreatectomy have been found to be feasible in selected patients [62-66]. However, for malignancies of the body and tail, further studies are required to confirm the potential benefits $[67,68]$. 
Intraoperative ultrasonography (IOUS) is a very sensitive $(93 \%)$ method to assess tumor resectability during surgery. And while it adds little time and no morbidity to the operation, it aids intra-operative decision-making [69].

\section{Role of modified appleby in distal pancreatic tumors}

The modified Appleby procedure consists of ligation of the celiac artery at its start point, common hepatic artery, along with distal pancreatectomy and removal of celiac plexus and ganglions, as well as, retroperitoneal tissues. The procedure is based on the presence of collateral circulation between the superior mesenteric artery and the hepatobiliary system by way of an intact pancreaticoduodenal arcade. This procedure has been indicated in locally advanced lesions involving the celiac axis without invasion of the head of the pancreas, and proper hepatic artery and superior mesenteric arteries [70]. There should be clear pulsations of the proper hepatic artery 1-2 min after occlusion of the common hepatic artery. The advantages of this radical procedure have been the ability to salvage locally advanced tumors, while decreasing postoperative pain due to the removal of the celiac plexus. While the results remain unsatisfactory as this procedure requires a tedious vascular workup, patients with celiac axis involvement secondary to central pancreatic tumors need not be regarded as unresectable [71].

\section{Surgical management of cystic pancreatic tumors}

The currently accepted guidelines are that for SCAs, an organ preserving resection should be carried out while for mucinous tumors, a more radical resection is advised [72]. A segmental or distal pancreatectomy with preservation of the spleen where possible is recommended [73-78]. Distal pancreatectomy with splenectomy should be carried out in patients with MCAC [79] In the case of IPMN, where the tendency is for the tumor to grow along the ducts rather than radially into the parenchyma, the resection margins must be examined by frozen section intra operatively to confirm the clearance of the margins. The overall 5-year survival nears $100 \%$ for SCA and even MCA where the resection margins are clear and there is no evidence of transmural invasion [20, 80]. Even in IPMNs containing carcinoma, 5-year survival is over $50 \%$ [81].

Walsh et al. [82] have even suggested that with the increasing incidence of 'incidentally' detected asymptomatic pancreatic cysts, if a mucinous neoplasm can be excluded with confidence, an EUS guided aspiration can be done and the patient followed up clinically and with interval imaging.

\section{Surgical management of endocrine tumors}

The basic principles of surgery in these tumors are to avoid blind resections. Surgery should be considered with cau- tion in these patients, as it is wise to adopt the adage that the treatment should not be more aggressive and symptom producing than either the lesion or the manifestations of the disease. While in localized lesions a radical surgery can be performed, in large lesions, a debulking surgery may be resorted to. The main surgeries done for these tumors are: enucleation for benign tumors like insulinomas and gastrinomas, and redical resection for most others that have a higher likelihood of being malignant [83].

Total gastrectomy, which was considered an integral part of gastrinoma treatment, is now regarded as obsolete except in few indolent cases due to the availability of proton pump inhibitors.

Every attempt should be made to localise the tumor preoperatively by use of imaging modalities. In the event that the tumor is not localised, the patient should be explored by a generous incision with a thorough intraoperative search for the lesions after adequate mobilisation of the body and tail of the pancreas. This is possible after dividing the peritoneal attachments along the superior and inferior border of the pancreas. By this maneuver, the entire pancreas can be felt between the fingers enabling detection of the lesions that, most often, are very small. Liberal use of intraoperative ultrasound is encouraged.

Evidence of multicentricity, lymph node metastasis, and hepatic metastasis should be sought at the time of surgery by way of sampling. In which case en bloc lymphadenectomy and hepatic resections should be resorted to when feasible [84-90].

\section{Role of segmental resections}

In the recent years, there have been increasing reports of organ sparing (central pancreatectomy) resections being undertaken for lesions in the body and tail [91-93]. The advantage of such resections is the lowered incidence of complications such as postoperative exocrine-endocrine dysfunction and post-splenectomy sepsis [91]. While this procedure is attractive, the reported pancreatic fistula rates after a central pancreatectomy have been reported to be as high as $51-63 \%$ $[91,94]$.

Another issue with central pancreatectomy is the risk of inadequate resections in the case of malignant tumors [94]. Hence it is indicated at the present time mainly for benign / low-grade malignant lesions or metastases to the neck or proximal body of the pancreas. The use of such resections for ductal adenocarcinomas is not indicated owing to the entirely different and aggressive tumor biology [95].

\section{Role of lymphadenectomy}

The role for extended lymphadenectomy in tumors of the body and tail has always been promulgated by Ozaki [96] and Shoup [16] on the premise that surgery is the only chance for 
cure. While assessing the prognostic factors affecting survival in pancreatic body and tail tumors, Shimada et al. [97], found that unlike tumors in the head where the portal vein presents the surgeon with a daunting vascular reconstruction, the invasion of the splenic vein is surgically easier to handle. The application of extended lymphadenectomy has provided the ability to precisely stage the tumor while ensuring a clear operative margin. Shimada concluded that despite his experience with no increased operative mortality with extended lymphadenectomy, further randomised trials are needed to establish it as a standard procedure for tumors of the body and tail.

\section{Complications after distal pancreatectomy}

The complications after surgery for the pancreatic body and tail tumors are classified into major and minor [48]. The major complications encountered include infections/abscess, pancreatic fistula, sepsis, small bowel fistula, upper GI bleed, and small bowel obstruction. The minor complications that can be encountered include fever, nausea/vomiting, tachycardia, edema, ileus, and respiratory complications.

\section{Role of chemotherapy and radiotherapy}

\section{Adjuvant therapy in resectable disease}

The use of gemcitabine vs 5FU, before, and after chemoradiation in resectable pancreatic adenocarcinomas [98] failed to show any improvement in survival in patients with tumors of the body and tail though patients who received gemcitabine did show a better 3-year survival.

\section{In locally advanced disease}

A randomized phase III study by the FFCD-SFRO [99] compared the use of initial chemoradiation followed by gemcitabine with gemcitabine alone in patients with locally advanced pancreatic cancer. The primary end point was overall survival (OS). The toxicity in the chemoradiotherapy arm probably led to the decreased use of maintenance gemcitabline in that arm. This led to a poor overall survival for the chemoradiotherapy arm leading the author to conclude that in locally advanced pancreatic cancer, gemcitabine should be the only drug used. Another study by Wilkowski et al. [100] has concluded that gemcitabine and 5FU can be safely combined with external beam radiotherapy to help achieve a secondary resection.

The studies examining the role of chemoradiotherapy in advanced pancreatic carcinoma are summarized in Table 5 (Saif MW - Online CME "Treatment of pancreatic cancer") [100-104].

Role of neoadjuvant chemotherapy along with radiotherapy in resectable disease

Two recent phase II trials explored the possibility of this intervention. Talamonti et al. [105] found that the benefit of the use of gemcitabine along with radiotherapy included a survival ranging up to 11 months but the toxicities and the low number of patients who could eventually undergo an R0 resection has not permitted the use of this routinely outside the confines of clinical trials. Mornex et al. [106] proposed that this pre-operative scheme is feasible, does not prevent successful surgery, and must be tested on a Phase III setting.

In cystic pancreatic tumors, as well, the role of chemoradiation requires more studies to prove it's efficacy as the currently available evidence is based on experimental experience with few patients and information acquired from case reports. The indications cited in available literature include evidence of tissue invasiveness [107-109] in the pathological specimen, liver metastasis (chemoembolization) [110], unresectable tumor (radiotherapy) [111], large tumors (neoadjuvant chemotherapy to downsize the tumor for surgery) [112], and with aneuploid neoplasms [113]. Sarr et al. have suggested a role for adjuvant treatment even in the absence

Table 5. Chemotherapy in advanced / metastatic pancreatic adenocarcinoma (Saif MW - Online CME "Treatment of pancreatic cancer) [101]

\begin{tabular}{llll}
\hline Study & Gemcitabine regimen & $\begin{array}{l}\text { Median Survival } \\
\text { (months) }\end{array}$ & $\begin{array}{l}\text { 1-year } \\
\text { survival }\end{array}$ \\
\hline Burris et al [102] & 30-minute infusion & 5.7 & $18 \%$ \\
Tempero et al [103] & Fixed dose rate & 7.8 & $24 \%$ \\
Louvet et al [104] & $\begin{array}{l}\text { Gemcitabine and } \\
\text { Oxaliplatin }\end{array}$ & 9.2 & $36 \%$ \\
\hline
\end{tabular}


of lymph node metastasis [4].

In endocrine tumors, the role for adjuvant treatment is immense. The various therapies used include biological modifiers, 1) Somatostatin Analogues: This group of drugs has been used in patients wherein the complete surgical removal of the tumor is not possible, or there is the presence of extensive liver metastases, wide-spread local invasion or rapid growth. The introduction of analogues with sustained release from depot injections, which can be given every 2 - 4 weeks, have made dosaging more convenient (Sandostatin LAR - monthly, Lanreotide - fortnightly, and lanreotide autogel - monthly). These drugs, lanreotide (fortnightly injection), Sandostatin LAR (monthly), and Lanreotide Autogel (also monthly), have been associated with significant improvement in the quality of life of patients [114-116]; 2) Targeted radionuclide therapy: The primary indications have been as palliation in patients who are inoperable, metastatic and progressive tumors with avid uptake of ${ }^{123}$ I-MIBG or ${ }^{111}$ In-octreotide at all known tumor sites on diagnostic imaging. Although no randomized controlled trials have been performed, current data is encouraging in terms of tumor stabilization. The isotopes used include ${ }^{123} \mathrm{I}-\mathrm{MIBG},{ }^{90} \mathrm{Y}$-octreotide for ${ }^{111} \mathrm{In}$-octreotate, and ${ }^{90} \mathrm{Y}$-lanreotide for ${ }^{111} \mathrm{In}$-lanreotide and ${ }^{177}$ lutetium. For ${ }^{131} \mathrm{I}-\mathrm{MIBG}$ therapy, symptom control is up to $80 \%$ with a 5-year survival rate of $60 \%$ [117-118]. For ${ }^{90} \mathrm{Y}$-octreotide therapy, the majority of patients achieve tumor stabilization although significant tumor regression is unusual [119-121]; 3) Interferons: Results utilizing interferon indicate a mean biochemical response rate of $40-60 \%$, symptomatic improvement in $40-70 \%$, and tumor shrinkage in about $10-15 \%$ [122-124].

\section{Chemotherapy}

The role of chemotherapy for endocrine pancreatic tumors is uncertain. Recommendations for well-differentiated endocrine carcinomas consist of combinations including permutations or streptozotocin, epirubicin, dacarbazine, 5-fluorouracil, and adriamycin, and response rates vary between $40 \%$ and $70 \%[125,126]$. The unpredictable response rates debilitating side effects in insulinomas, carcinoids, and VIPomas limit their use in these tumors. Response rates of $>70 \%$ to cisplatin and etoposide combination chemotherapy have been seen in the poorly differentiated and anaplastic endocrine pancreatic tumors $[127,128]$.

\section{Emerging therapies}

Targeted therapy in exocrine pancreatic tumors, an approach to combating pancreatic tumors, has emerged owing to the better understanding of the molecular biology of pancreatic cancer, and the envisaged marginal benefits that can be obtained even with the best chemotherapeutic regimens. The main receptor that is being targeted today is the ErbB recep- tors viz., ErbB1 - EGFR, and ErbB2 - Her2. Cetuximab, a humanized monoclonal antibody to ErbB1 [129] and Trastuzumab, an antibody to Her2 [130] are currently being used in combination with gemcitabine. Trials are on to evaluate the role of matrix metalloproteinases [131].

Novel somatostatin radionuclide therapies are currently in development. ${ }^{188}$ Re-octreotide may be substituted for ${ }^{99} \mathrm{mTc}-E D T A-H Y N I C-o c t r e o t i d e ~[16] . ~{ }^{177} \mathrm{Lu}$-octreotate therapy has been recently introduced [132]. Other novel agents involving cell signaling transduction blockers (e.g. Gifitinib), which affect tyrosine kinase and a variety of angiogenesis inhibitors are under investigation.

\section{Prognosis}

The 5-year survival rate of pancreatic body and tail tumors after surgical resection ranges from $0-25 \%$, and the median survival time is $10-15.9$ months $[16,48,133-135]$. This post resection survival rate, however, does not differ depending on whether the tumor is in the head, body, or tail [48].

\section{References}

1. Wilentz RE, Hruban RH. Pathology of cancer of the pancreas. Surg Oncol Clin N Am 1998;7(1):43-65.

2. Zamboni G, Scarpa A, Bogina G, Iacono C, Bassi C, Talamini G, Sessa F, et al. Mucinous cystic tumors of the pancreas: clinicopathological features, prognosis, and relationship to other mucinous cystic tumors. Am J Surg Pathol 1999;23(4):410-422.

3. Goh BK, Tan YM, Cheow PC, Chung YF, Chow PK, Wong WK, Ooi LL. Cystic neoplasms of the pancreas with mucin-production. Eur J Surg Oncol 2005;31(3):282-287.

4. Sarr MG, Carpenter HA, Prabhakar LP, Orchard TF, Hughes S, van Heerden JA, DiMagno EP. Clinical and pathologic correlation of 84 mucinous cystic neoplasms of the pancreas: can one reliably differentiate benign from malignant (or premalignant) neoplasms? Ann Surg 2000;231(2):205-212.

5. Adsay NV, Longnecker DS, Klimstra DS. Pancreatic tumors with cystic dilatation of the ducts: intraductal papillary mucinous neoplasms and intraductal oncocytic papillary neoplasms. Semin Diagn Pathol 2000;17(1):16-30.

6. Nakamura A, Horinouchi M, Goto M, Nagata K, Sakoda $\mathrm{K}$, Takao S, Imai K, et al. New classification of pancreatic intraductal papillary-mucinous tumour by mucin expression: its relationship with potential for malignancy. J Pathol 2002;197(2):201-210.

7. Adsay NV, Conlon KC, Zee SY, Brennan MF, Klimstra DS. Intraductal papillary-mucinous neoplasms of the 
pancreas: an analysis of in situ and invasive carcinomas in 28 patients. Cancer 2002;94(1):62-77.

8. Furukawa T, Kloppel G, Volkan Adsay N, AlboresSaavedra J, Fukushima N, Horii A, Hruban RH, et al. Classification of types of intraductal papillary-mucinous neoplasm of the pancreas: a consensus study. Virchows Arch 2005;447(5):794-799.

9. Sarr MG, Murr M, Smyrk TC, Yeo CJ, Fernandez-delCastillo C, Hawes RH, Freeny PC. Primary cystic neoplasms of the pancreas. Neoplastic disorders of emerging importance-current state-of-the-art and unanswered questions. J Gastrointest Surg 2003;7(3):417-428.

10. Mohan H, Bal A, Punia RP, Attri AK. Solid and cystic papillary epithelial neoplasm of the pancreas. J Postgrad Med 2006;52(2):141-142.

11. Kasem A, Ali Z, Ellul J. Papillary cystic and solid tumour of the pancreas: report of a case and literature review. World J Surg Oncol 2005;3:62.

12. Beauchamp RD, Thompson JC. Endocrine tumors of the pancreas. In: Zinner MJ, Schwartz SI, Ellis H, editors. Maingot's Abdominal Operations. 10th edn. Appleton and Lange; 1997. pp1961-1976.

13. Kaplan EL, Fredland A. The diagnosis and treatment of insulinomas. Philadelphia: W. B. Saunders; 1983

14. Stabile BE, Morrow DJ, Passaro E, Jr. The gastrinoma triangle: operative implications. Am J Surg 1984;147(1):25-31.

15. Cowgill SM, Muscarella P. The genetics of pancreatic cancer. Am J Surg 2003;186(3):279-286.

16. Shoup M, Conlon KC, Klimstra D, Brennan MF. Is extended resection for adenocarcinoma of the body or tail of the pancreas justified? J Gastrointest Surg 2003;7(8):946-952; discussion 952.

17. Christein JD, Kendrick ML, Iqbal CW, Nagorney DM, Farnell MB. Distal pancreatectomy for resectable adenocarcinoma of the body and tail of the pancreas. J Gastrointest Surg 2005;9(7):922-927.

18. de Calan L, Levard H, Hennet H, Fingerhut A. Pancreatic cystadenoma and cystadenocarcinoma: diagnostic value of preoperative morphological investigations. Eur J Surg 1995;161(1):35-40.

19. Brennan MF. Periampullary and pancreatic cancer. In: Blumgart LH, Fong Y, editors. Surgery of the liver and biliary tract. Third edn. W. B. Saunders; 2000. pp 10591071.

20. Sakorafas GH, Sarr MG. Cystic neoplasms of the pancreas; what a clinician should know. Cancer Treat Rev 2005;31(7):507-535.

21. Lim SJ, Alasadi R, Wayne JD, Rao S, Rademaker A, Bell R, Talamonti MS. Preoperative evaluation of pancreatic cystic lesions: cost-benefit analysis and proposed management algorithm. Surgery 2005;138(4):672-679; discussion 679-680.

22. Kiely JM, Nakeeb A, Komorowski RA, Wilson SD, Pitt
HA. Cystic pancreatic neoplasms: enucleate or resect? J Gastrointest Surg 2003;7(7):890-897.

23. Leung KL, Lau WY, Cooper JE, Li AK. Mucinous cystadenocarcinoma of the pancreas: an uncommon presentation with hemobilia. Gastrointest Endosc 1994;40(5):632-634.

24. Baruch Y, Levy Y, Goldsher D, Munichor M, Eidelman S. Massive haematemesis--presenting symptoms of cystadenocarcinoma of the pancreas. Postgrad Med J 1989;65(759):42-44.

25. Raffel A, Cupisti K, Krausch M, Braunstein S, Trobs B, Goretzki PE, Willnow U. Therapeutic strategy of papillary cystic and solid neoplasm (PCSN): a rare non-endocrine tumor of the pancreas in children. Surg Oncol 2004;13(1):1-6.

26. Yamaguchi K, Ogawa Y, Chijiiwa K, Tanaka M. Mucin-hypersecreting tumors of the pancreas: assessing the grade of malignancy preoperatively. Am J Surg 1996;171(4):427-431.

27. Margolis RM, Jang N. Zollinger-Ellison syndrome associated with pancreatic cystadenocarcinoma. N Engl J Med 1984;311(21):1380-1381.

28. Pauwels M, Delcenserie R, Yzet T, Duchmann JC, Capron JP. Pancreatic cystadenocarcinoma in Peutz-Jeghers syndrome. J Clin Gastroenterol 1997;25(2):485-486.

29. Whipple AO, Frantz VK. Adenoma of Islet Cells with Hyperinsulinism: A Review. Ann Surg 1935;101(6):12991335 .

30. Deveney CW, Deveney KE. Zollinger-Ellison syndrome (gastrinoma). Current diagnosis and treatment. Surg Clin North Am 1987;67(2):411-422.

31. Higgins GA, Recant L, Fischman AB. The glucagonoma syndrome: surgically curable diabetes. Am J Surg 1979;137(1):142-148.

32. Horwhat JD, Gress FG. Defining the diagnostic algorithm in pancreatic cancer. JOP 2004;5(4):289-303.

33. Santo E. Pancreatic cancer imaging: which method? JOP 2004;5(4):253-257.

34. Soriano A, Castells A, Ayuso C, Ayuso JR, de Caralt MT, Gines MA, Real MI, et al. Preoperative staging and tumor resectability assessment of pancreatic cancer: prospective study comparing endoscopic ultrasonography, helical computed tomography, magnetic resonance imaging, and angiography. Am J Gastroenterol 2004;99(3):492-501.

35. Bipat S, Phoa SS, van Delden OM, Bossuyt PM, Gouma DJ, Lameris JS, Stoker J. Ultrasonography, computed tomography and magnetic resonance imaging for diagnosis and determining resectability of pancreatic adenocarcinoma: a meta-analysis. J Comput Assist Tomogr 2005;29(4):438-445.

36. Sica GT, Ji H, Ros PR. Computed tomography and magnetic resonance imaging of hepatic metastases. Clin Liver Dis 2002;6(1):165-179, vii. 
37. Michl P, Pauls S, Gress TM. Evidence-based diagnosis and staging of pancreatic cancer. Best Pract Res Clin Gastroenterol 2006;20(2):227-251.

38. Li H, Zeng MS, Zhou KR, Jin DY, Lou WH. Pancreatic adenocarcinoma: the different CT criteria for peripancreatic major arterial and venous invasion. J Comput Assist Tomogr 2005;29(2):170-175.

39. Chang KJ, Nguyen P, Erickson RA, Durbin TE, Katz KD. The clinical utility of endoscopic ultrasound-guided fine-needle aspiration in the diagnosis and staging of pancreatic carcinoma. Gastrointest Endosc 1997;45(5):387393.

40. Stefanidis D, Grove KD, Schwesinger WH, Thomas $\mathrm{CR}$, Jr. The current role of staging laparoscopy for adenocarcinoma of the pancreas: a review. Ann Oncol 2006;17(2):189-199.

41. Jimenez RE, Warshaw AL, Rattner DW, Willett CG, McGrath D, Fernandez-del Castillo C. Impact of laparoscopic staging in the treatment of pancreatic cancer. Arch Surg 2000;135(4):409-414; discussion 414-405.

42. Liu RC, Traverso LW. Diagnostic laparoscopy improves staging of pancreatic cancer deemed locally unresectable by computed tomography. Surg Endosc 2005;19(5):638642.

43. Vogt DP. Pancreatic cancer: a current overview. Curr Surg 2000;57(3):214-220.

44. Kehagias D, Smyrniotis V, Kalovidouris A, Gouliamos A, Kostopanagiotou E, Vassiliou J, Vlahos L. Cystic tumors of the pancreas: preoperative imaging, diagnosis, and treatment. Int Surg 2002;87(3):171-174.

45. Sperti C, Pasquali C, Chierichetti F, Liessi G, Ferlin G, Pedrazzoli S. Value of 18-fluorodeoxyglucose positron emission tomography in the management of patients with cystic tumors of the pancreas. Ann Surg 2001;234(5):675-680.

46. Exocrine Pancreas. In: American Joint Committee on Cancer. AJCC Cancer Staging Manual. 6th ed. New York, NY: Springer, 2002, pp157-164.

47. Pancreatic Adenocarcinoma. NCCN Clinical Practice Guidelines in Oncology. Version 2. 2006 (www.nccn. org)

48. Brennan MF, Moccia RD, Klimstra D. Management of adenocarcinoma of the body and tail of the pancreas. Ann Surg 1996;223(5):506-511; discussion 511-502.

49. Balcom JHt, Rattner DW, Warshaw AL, Chang Y, Fernandez-del Castillo C. Ten-year experience with 733 pancreatic resections: changing indications, older patients, and decreasing length of hospitalization. Arch Surg 2001;136(4):391-398.

50. Lillemoe KD, Kaushal S, Cameron JL, Sohn TA, Pitt HA, Yeo CJ. Distal pancreatectomy: indications and outcomes in 235 patients. Ann Surg 1999;229(5):693-698; discussion 698-700.

51. Aldridge MC, Williamson RC. Distal pancreatectomy with and without splenectomy. Br J Surg 1991;78(8):976979.

52. Fahy BN, Frey CF, Ho HS, Beckett L, Bold RJ. Morbidity, mortality, and technical factors of distal pancreatectomy. Am J Surg 2002;183(3):237-241.

53. Yan HC, Wu YL, Chen LR, Gao SL. Resection of noncystic adenocarcinoma in pancreatic body and tail. World J Gastroenterol 2006;12(35):5726-5728.

54. Sasson AR, Hoffman JP, Ross EA, Kagan SA, Pingpank JF, Eisenberg BL. En bloc resection for locally advanced cancer of the pancreas: is it worthwhile? J Gastrointest Surg 2002;6(2):147-157; discussion 157-148.

55. Ridolfini MP, Alfieri S, Gourgiotis S, Di Miceli D, Rotondi F, Quero G, Manghi R, et al. Risk factors associated with pancreatic fistula after distal pancreatectomy, which technique of pancreatic stump closure is more beneficial? World J Gastroenterol 2007;13(38):50965100 .

56. Takeuchi K, Tsuzuki Y, Ando T, Sekihara M, Hara T, Kori T, Nakajima H, et al. Distal pancreatectomy: is staple closure beneficial? ANZ J Surg 2003;73(11):922925.

57. Knaebel HP, Diener MK, Wente MN, Buchler MW, Seiler CM. Systematic review and meta-analysis of technique for closure of the pancreatic remnant after distal pancreatectomy. Br J Surg 2005;92(5):539-546.

58. Kleeff J, Diener MK, Z'Graggen K, Hinz U, Wagner M, Bachmann J, Zehetner J, et al. Distal pancreatectomy: risk factors for surgical failure in 302 consecutive cases. Ann Surg 2007;245(4):573-582.

59. D'Souza M A, Shrikhande SV. Pancreatic resectional surgery: an evidence-based perspective. J Cancer Res Ther 2008;4(2):77-83.

60. Shoup M, Brennan MF, McWhite K, Leung DH, Klimstra D, Conlon KC. The value of splenic preservation with distal pancreatectomy. Arch Surg 2002;137(2):164168.

61. Doucas H, Sutton CD, Zimmerman A, Dennison AR, Berry DP. Assessment of pancreatic malignancy with laparoscopy and intraoperative ultrasound. Surg Endosc 2007;21(7):1147-1152.

62. Patterson EJ, Gagner M, Salky B, Inabnet WB, Brower S, Edye M, Gurland B, et al. Laparoscopic pancreatic resection: single-institution experience of 19 patients. J Am Coll Surg 2001;193(3):281-287.

63. Fabre JM, Dulucq JL, Vacher C, Lemoine MC, Wintringer P, Nocca D, Burgel JS, et al. Is laparoscopic left pancreatic resection justified? Surg Endosc 2002;16(9):1358-1361.

64. Fernandez-Cruz L, Saenz A, Astudillo E, Martinez I, Hoyos S, Pantoja JP, Navarro S. Outcome of laparoscopic pancreatic surgery: endocrine and nonendocrine tumors. World J Surg 2002;26(8):1057-1065.

65. Edwin B, Mala T, Mathisen O, Gladhaug I, Buanes T, 
Lunde OC, Soreide O, et al. Laparoscopic resection of the pancreas: a feasibility study of the short-term outcome. Surg Endosc 2004;18(3):407-411.

66. Khanna A, Koniaris LG, Nakeeb A, Schoeniger LO. Laparoscopic spleen-preserving distal pancreatectomy. J Gastrointest Surg 2005;9(5):733-738.

67. Lebedyev A, Zmora O, Kuriansky J, Rosin D, Khaikin M, Shabtai M, Ayalon A. Laparoscopic distal pancreatectomy. Surg Endosc 2004;18(10):1427-1430.

68. Long EE, Van Dam J, Weinstein S, Jeffrey B, Desser T, Norton JA. Computed tomography, endoscopic, laparoscopic, and intra-operative sonography for assessing resectability of pancreatic cancer. Surg Oncol 2005;14(2):105-113.

69. Shrikhande SV, Barreto SG, Shukla PJ. Lapaproscopy in pancreatic tumors. J Min Access Surg 2007; 3: 47-51

70. Liu B. Modified Appleby operation in treatment of distal pancreatic cancer. Hepatobiliary Pancreat Dis Int 2003;2(4):622-625.

71. Gagandeep S, Artinyan A, Jabbour N, Mateo R, Matsuoka L, Sher L, Genyk Y, et al. Extended pancreatectomy with resection of the celiac axis: the modified Appleby operation. Am J Surg 2006;192(3):330-335.

72. Siech M, Thumerer SU, Henne-Bruns D, Beger HG. [Cystic tumors of the pancreas-radical or organ-preserving resection?]. Chirurg 2004;75(6):615-621.

73. Iacono C, Bortolasi L, Serio G. Is there a place for central pancreatectomy in pancreatic surgery? J Gastrointest Surg 1998;2(6):509-516; discussion 516-507.

74. Warren KW, Athanassiades S, Frederick P, Kune GA. Surgical treatment of pancreatic cysts: review of 183 cases. Ann Surg 1966;163(6):886-891.

75. Lukish JR, Rothstein JH, Petruzziello M, Kiteley R, Denobile J, Soballe P. Spleen-preserving pancreatectomy for cystic pancreatic neoplasms. Am Surg 1999;65(6):596-599.

76. Kimura W, Fuse A, Hirai I, Suto K, Suzuki A, Moriya T, Sakurai F. Spleen-preserving distal pancreatectomy with preservation of the splenic artery and vein for intraductal papillary-mucinous tumor (IPMT): three interesting cases. Hepatogastroenterology 2003;50(54):2242-2245.

77. Molino D, Perrotti P, Antropoli C, Bottino V, Napoli V, Fioretto R. [Central segmental pancreatectomy in benign and borderline neoplasms of the pancreatic isthmus and body]. Chir Ital 2001;53(3):319-325.

78. Barreto G, Shukla PJ, Ramadwar M, Arya S, Shrikhande SV. Cystic tumours of the pancreas. HPB (Oxford) 2007;9(4):259-266.

79. Talamini MA, Moesinger R, Yeo CJ, Poulose B, Hruban RH, Cameron JL, Pitt HA. Cystadenomas of the pancreas: is enucleation an adequate operation? Ann Surg 1998;227(6):896-903.

80. Brugge WR, Lauwers GY, Sahani D, Fernandez-del Castillo C, Warshaw AL. Cystic neoplasms of the pan- creas. N Engl J Med 2004;351(12):1218-1226.

81. Chari ST, Yadav D, Smyrk TC, DiMagno EP, Miller LJ, Raimondo M, Clain JE, et al. Study of recurrence after surgical resection of intraductal papillary mucinous neoplasm of the pancreas. Gastroenterology 2002;123(5):1500-1507.

82. Walsh RM, Vogt DP, Henderson JM, Zuccaro G, Vargo J, Dumot J, Herts B, et al. Natural history of indeterminate pancreatic cysts. Surgery 2005;138(4):665-670; discussion 670-661.

83. Norton JA. Neuroendocrine tumors of the pancreas and duodenum. Curr Probl Surg 1994;31(2):77-156.

84. Touzios JG, Kiely JM, Pitt SC, Rilling WS, Quebbeman EJ, Wilson SD, Pitt HA. Neuroendocrine hepatic metastases: does aggressive management improve survival? Ann Surg 2005;241(5):776-783; discussion 783-775.

85. Chen H, Hardacre JM, Uzar A, Cameron JL, Choti MA. Isolated liver metastases from neuroendocrine tumors: does resection prolong survival? J Am Coll Surg 1998;187(1):88-92; discussion 92-83.

86. Sarmiento JM, Heywood G, Rubin J, Ilstrup DM, Nagorney DM, Que FG. Surgical treatment of neuroendocrine metastases to the liver: a plea for resection to increase survival. J Am Coll Surg 2003;197(1):29-37.

87. Schurr PG, Strate T, Rese K, Kaifi JT, Reichelt U, Petri S, Kleinhans H, et al. Aggressive surgery improves long-term survival in neuroendocrine pancreatic tumors: an institutional experience. Ann Surg 2007;245(2):273281.

88. Musunuru S, Chen H, Rajpal S, Stephani N, McDermott JC, Holen K, Rikkers LF, et al. Metastatic neuroendocrine hepatic tumors: resection improves survival. Arch Surg 2006;141(10):1000-1004; discussion 1005.

89. Nomura N, Fujii T, Kanazumi N, Takeda S, Nomoto S, Kasuya H, Sugimoto H, et al. Nonfunctioning neuroendocrine pancreatic tumors: our experience and management. J Hepatobiliary Pancreat Surg 2009;16(5):639647.

90. Bilimoria KY, Talamonti MS, Tomlinson JS, Stewart AK, Winchester DP, Ko CY, Bentrem DJ. Prognostic score predicting survival after resection of pancreatic neuroendocrine tumors: analysis of 3851 patients. Ann Surg 2008;247(3):490-500.

91. Bassi C. Middle segment pancreatectomy: a useful tool in the management of pancreatic neoplasms. J Gastrointest Surg 2007;11(6):726-729.

92. Christein JD, Smoot RL, Farnell MB. Central pancreatectomy: a technique for the resection of pancreatic neck lesions. Arch Surg 2006;141(3):293-299.

93. Crippa S, Bassi C, Warshaw AL, Falconi M, Partelli S, Thayer SP, Pederzoli P, et al. Middle pancreatectomy: indications, short- and long-term operative outcomes. Ann Surg 2007;246(1):69-76.

94. Reber HA. Middle pancreatectomy: why I rarely do it. J 
Gastrointest Surg 2007;11(6):730-732.

95. Glanemann M, Shi B, Liang F, Sun XG, Bahra M, Jacob D, Neumann U, et al. Surgical strategies for treatment of malignant pancreatic tumors: extended, standard or local surgery? World J Surg Oncol 2008;6:123.

96. Ozaki H, Kinoshita T, Kosuge T, Yamamoto J, Shimada $\mathrm{K}$, Inoue K, Koyama Y, et al. An aggressive therapeutic approach to carcinoma of the body and tail of the pancreas. Cancer 1996;77(11):2240-2245.

97. Shimada K, Sakamoto Y, Sano T, Kosuge T. Prognostic factors after distal pancreatectomy with extended lymphadenectomy for invasive pancreatic adenocarcinoma of the body and tail. Surgery 2006;139(3):288-295.

98. Regine WF, Winter KW, Abrams R, et al. RTOG 9704: a phase III study of adjuvant pre and post chemoradiation 5-FU vs. gemcitabine for resected pancreatic adenocarcinoma. J. Clin. Oncol. 2006; 24(18S, Part I): 4007. ASCO Annual Meeting.

99. Chauffert B, Mornex F, Bonnetain F, et al. Phase III trial comparing initial chemoradiotherapy (intermittent cisplatin and infusional 5-FU) followed by gemcitabine vs. gemcitabine alone in patients with locally advanced (LA) non-metastatic pancreatic cancer. J Clin Oncol 2006; 24(18S, Part I): 4008. ASCO Annual Meeting.

100. Wilkowski R, Thoma M, Bruns C, Wagner A, Heinemann V. Chemoradiotherapy with gemcitabine and continuous 5-FU in patients with primary inoperable pancreatic cancer. JOP 2006;7(4):349-360.

101. Saif MW. Pancreatic cancer: highlights from the 42nd annual meeting of the American Society of Clinical Oncology, 2006. JOP 2006;7(4):337-348.

102. Burris HA, 3rd, Moore MJ, Andersen J, Green MR, Rothenberg ML, Modiano MR, Cripps MC, et al. Improvements in survival and clinical benefit with gemcitabine as first-line therapy for patients with advanced pancreas cancer: a randomized trial. J Clin Oncol 1997;15(6):2403-2413.

103. Tempero M, Plunkett W, Ruiz Van Haperen V, Hainsworth J, Hochster H, Lenzi R, Abbruzzese J. Randomized phase II comparison of dose-intense gemcitabine: thirty-minute infusion and fixed dose rate infusion in patients with pancreatic adenocarcinoma. J Clin Oncol 2003;21(18):3402-3408.

104. Louvet C, Labianca R, Hammel P, Lledo G, Zampino MG, Andre T, Zaniboni A, et al. Gemcitabine in combination with oxaliplatin compared with gemcitabine alone in locally advanced or metastatic pancreatic cancer: results of a GERCOR and GISCAD phase III trial. J Clin Oncol 2005;23(15):3509-3516.

105. Talamonti MS, Small W, Jr., Mulcahy MF, Wayne JD, Attaluri V, Colletti LM, Zalupski MM, et al. A multiinstitutional phase II trial of preoperative full-dose gemcitabine and concurrent radiation for patients with potentially resectable pancreatic carcinoma. Ann Surg
Oncol 2006;13(2):150-158.

106. Mornex F, Girard N, Scoazec JY, Bossard N, Ychou M, Smith D, Seitz JF, et al. Feasibility of preoperative combined radiation therapy and chemotherapy with 5-fluorouracil and cisplatin in potentially resectable pancreatic adenocarcinoma: The French SFROFFCD 97-04 Phase II trial. Int J Radiat Oncol Biol Phys 2006;65(5):1471-1478.

107. Doberstein C, Kirchner R, Gordon L, Silberman AW, Morgenstern L, Shapiro S. Cystic neoplasms of the pancreas. Mt Sinai J Med 1990;57(2):102-105.

108. George DH, Murphy F, Michalski R, Ulmer BG. Serous cystadenocarcinoma of the pancreas: a new entity? Am J Surg Pathol 1989;13(1):61-66.

109. Maire F, Hammel P, Terris B, Paye F, Scoazec JY, Cellier C, Barthet M, et al. Prognosis of malignant intraductal papillary mucinous tumours of the pancreas after surgical resection. Comparison with pancreatic ductal adenocarcinoma. Gut 2002;51(5):717-722.

110. Matsuda Y, Imai Y, Kawata S, Nishikawa M, Miyoshi S, Saito R, Minami Y, et al. Papillary-cystic neoplasm of the pancreas with multiple hepatic metastases: a case report. Gastroenterol Jpn 1987;22(3):379-384.

111. Fried P, Cooper J, Balthazar E, Fazzini E, Newall J. A role for radiotherapy in the treatment of solid and papillary neoplasms of the pancreas. Cancer 1985;56(12):27832785.

112. Das G, Bhuyan C, Das BK, Sharma JD, Saikia BJ, Purkystha J. Spleen-preserving distal pancreatectomy following neoadjuvant chemotherapy for papillary solid and cystic neoplasm of pancreas. Indian J Gastroenterol 2004;23(5):188-189.

113. Brenin DR, Talamonti MS, Yang EY, Sener SF, Haines GK, Joehl RJ, Nahrwold DL. Cystic neoplasms of the pancreas. A clinicopathologic study, including DNA flow cytometry. Arch Surg 1995;130(10):1048-1054.

114. Ruszniewski P, Ducreux M, Chayvialle JA, Blumberg J, Cloarec D, Michel H, Raymond JM, et al. Treatment of the carcinoid syndrome with the longacting somatostatin analogue lanreotide: a prospective study in 39 patients. Gut 1996;39(2):279-283.

115. Tomassetti P, Migliori M, Corinaldesi R, Gullo L. Treatment of gastroenteropancreatic neuroendocrine tumours with octreotide LAR. Aliment Pharmacol Ther 2000;14(5):557-560.

116. Garland J, Buscombe JR, Bouvier C, Bouloux P, Chapman $\mathrm{MH}$, Chow AC, Reynolds N, et al. Sandostatin LAR (long-acting octreotide acetate) for malignant carcinoid syndrome: a 3-year experience. Aliment Pharmacol Ther 2003;17(3):437-444.

117. Mukherjee JJ, Kaltsas GA, Islam N, Plowman PN, Foley R, Hikmat J, Britton KE, et al. Treatment of metastatic carcinoid tumours, phaeochromocytoma, paraganglioma and medullary carcinoma of the thyroid with 
(131)I-meta-iodobenzylguanidine [(131)I-mIBG]. Clin Endocrinol (Oxf) 2001;55(1):47-60.

118. Pathirana AA, Vinjamuri S, Byrne C, Ghaneh P, Vora J, Poston GJ. (131)I-MIBG radionuclide therapy is safe and cost-effective in the control of symptoms of the carcinoid syndrome. Eur J Surg Oncol 2001;27(4):404408.

119. Krenning EP, Valkema R, Kooij PP, Breeman WA, Bakker WH, de Herder WW, van Eijck $\mathrm{CH}$, et al. The role of radioactive somatostatin and its analogues in the control of tumor growth. Recent Results Cancer Res 2000;153:1-13.

120. Krenning EP, Valkema R, Kooij PP, Breeman WA, Bakker WH, deHerder WW, vanEijck $\mathrm{CH}$, et al. Scintigraphy and radionuclide therapy with [indium-111labelled-diethyl triamine penta-acetic acid-D-Phe1] octreotide. Ital J Gastroenterol Hepatol 1999;31 Suppl 2:S219-223.

121. Buscombe JR, Caplin ME, Hilson AJ. Long-term efficacy of high-activity 111 in-pentetreotide therapy in patients with disseminated neuroendocrine tumors. J Nucl Med 2003;44(1):1-6.

122. Oberg K. Interferon-alpha versus somatostatin or the combination of both in gastro-enteropancreatic tumours. Digestion 1996;57 Suppl 1:81-83.

123. Frank M, Klose KJ, Wied M, Ishaque N, Schade-Brittinger C, Arnold R. Combination therapy with octreotide and alpha-interferon: effect on tumor growth in metastatic endocrine gastroenteropancreatic tumors. Am J Gastroenterol 1999;94(5):1381-1387.

124. Oberg K, Funa K, Alm G. Effects of leukocyte interferon on clinical symptoms and hormone levels in patients with mid-gut carcinoid tumors and carcinoid syndrome. N Engl J Med 1983;309(3):129-133.

125. Bajetta E, Ferrari L, Procopio G, Catena L, Ferrario E, Martinetti A, Di Bartolomeo M, et al. Efficacy of a chemotherapy combination for the treatment of metastatic neuroendocrine tumours. Ann Oncol 2002;13(4):614621.

126. Bajetta E, Rimassa L, Carnaghi C, Seregni E, Ferrari L, Di Bartolomeo M, Regalia E, et al. 5-Fluorouracil, dacarbazine, and epirubicin in the treatment of patients with neuroendocrine tumors. Cancer 1998;83(2):372378.

127. Moertel CG, Lefkopoulo M, Lipsitz S, Hahn RG, Klaassen D. Streptozocin-doxorubicin, streptozocin-fluorouracil or chlorozotocin in the treatment of advanced islet-cell carcinoma. N Engl J Med 1992;326(8):519523.

128. Mitry E, Baudin E, Ducreux M, Sabourin JC, Rufie P, Aparicio T, Lasser P, et al. Treatment of poorly differentiated neuroendocrine tumours with etoposide and cisplatin. Br J Cancer 1999;81(8):1351-1355.

129. Xiong HQ, Rosenberg A, LoBuglio A, Schmidt W, Wolff RA, Deutsch J, Needle M, et al. Cetuximab, a monoclonal antibody targeting the epidermal growth factor receptor, in combination with gemcitabine for advanced pancreatic cancer: a multicenter phase II Trial. J Clin Oncol 2004;22(13):2610-2616.

130. Safran H, Iannitti D, Ramanathan R, Schwartz JD, Steinhoff M, Nauman C, Hesketh P, et al. Herceptin and gemcitabine for metastatic pancreatic cancers that overexpress HER-2/neu. Cancer Invest 2004;22(5):706712.

131. Li D, Xie K, Wolff R, Abbruzzese JL. Pancreatic cancer. Lancet 2004;363(9414):1049-1057.

132. Kwekkeboom DJ, Teunissen JJ, Bakker WH, Kooij PP, de Herder WW, Feelders RA, van Eijck CH, et al. Radiolabeled somatostatin analog [177Lu-DOTA0,Tyr3] octreotate in patients with endocrine gastroenteropancreatic tumors. J Clin Oncol 2005;23(12):2754-2762.

133. Sperti C, Pasquali C, Pedrazzoli S. Ductal adenocarcinoma of the body and tail of the pancreas. J Am Coll Surg 1997;185(3):255-259.

134. Kayahara M, Nagakawa T, Ueno K, Ohta T, Kitagawa H, Arakawa H, Yagi H, et al. Distal pancreatectomy-does it have a role for pancreatic body and tail cancer. Hepatogastroenterology 1998;45(21):827-832.

135. Burcharth F, Trillingsgaard J, Olsen SD, Moesgaard F, Federspiel B, Struckmann JR. Resection of cancer of the body and tail of the pancreas. Hepatogastroenterology 2003;50(50):563-566. 